\title{
In vitro Evaluation of Antibacterial, Cytotoxic and Adherence Studies of Selected Commercial Probiotics
}

\author{
Kolli Guna Ranjan ${ }^{1 *}$ (D) Girija Sankar G. ${ }^{\mathbb{D}}$, and D.V.V. Satyanarayana Raju ${ }^{3}$ \\ ${ }^{1}$ GITAM Institute of Pharmacy, GITAM University, Visakhapatnam - 530 017, Andhra Pradesh, India. \\ ${ }^{2}$ College of Pharmaceutical Science, Andhra University, Visakhapatnam -530 003, Andhra Pradesh, India. \\ ${ }^{3}$ FOR U International Private Limited, East point colony, Visakhapatnam - 530 003, Andhra Pradesh, India.
}

\begin{abstract}
There is increasing scientific evidence and commercial interest for using probiotics for eliminating and handling of specific diseases. Probiotics can be evaluated for its role and performance against isolated pathogens from contaminating sources. The present work reports on invitro antimicrobial activity of commercial selected probiotics against pathogenic microbe Vibrio parahaemolyticus. The work also describes cytotoxic activities using MTT assay and adherence studies of selected probiotics. Results for the studies showed maximum zone of inhibition $13.66 \pm 0.46 \mathrm{~mm}$ in probiotic enteroplus, $12.33 \pm 0.93 \mathrm{~mm}$ in lactobacillus (NCIM2056) and 10.66 $\pm 0.93 \mathrm{~mm}$ in Avant Bact. Cytotoxicity was expressed as IC50( $\mu \mathrm{g} /$ $\mathrm{ml}$ ) values, observed on CaCO cell lines for different probiotics. Avant Bact showed a IC50 value of 104.7745, Lactobacillus (NCIM2056) a value of 58.13223 and Enteroplus a value of 50.09716. These values expressed different safety aspects of probiotics used for study. Finally the adherence study was done to check probiotic colonizing capacity. The probiotics showed varied adherence capacity against caco cell lines. Enteroplus has \% adhesion of 10.25 \pm 0.74 , Avant Bact. $7.25 \pm 0.82$ and Lactobacillus (NCIM2056) 7.5 \pm 1.12 . In conclusion antimicrobial results show importance of probiotics to be used against specific gastro intestinal diseases. Cytotoxicity determines safety aspects of probiotics and adherence study determines probiotic as a promising candidate for in vivo studies
\end{abstract}

Keywords: Vibrio parahaemolyticus, Enteroplus, Avant Bact., antimicrobial, cytotoxicity, adherence

*Correspondence: gunaranjankolli@gmail.com; +91 8978973377

(Received: July 9, 2020; accepted: August 24, 2020)

Citation: Ranjan KG, Sankar GG, Raju DVVS. In vitro Evaluation of Antibacterial, Cytotoxic and Adherence Studies of Selected Commercial Probiotics. J Pure Appl Microbiol. 2020;14(3):2085-2091. doi: 10.22207/JPAM.14.3.49

(C) The Author(s) 2020. Open Access. This article is distributed under the terms of the Creative Commons Attribution 4.0 International License which permits unrestricted use, sharing, distribution, and reproduction in any medium, provided you give appropriate credit to the original author(s) and the source, provide a link to the Creative Commons license, and indicate if changes were made. 


\section{INTRODUCTION}

The gastrointestinal tract (GIT) of humans are associated with beneficial bacteria within our food supply. Probiotics being beneficial exhibit symbiotic relation with GIT, which has an impact on health and wellbeing. The gut microbiota exhibits beneficial effects on the host by having a positive impact on epithelial proliferation, metabolism and survival. It plays various roles in managing microbial groups by restricting pathogen colonization by producing antimicrobials, increasing mucin production, competing for adhesion sites and optimization of microbiota composition ${ }^{1}$. Disturbances in the GI tract occurring due to poor diet, infections and intake of antibiotics leads to dysbiosis. Probiotics have been sought as an alternative for reducing illness and preventing antibiotic associated diarrhoea and acute gastroenteritis. Some desirable properties for selecting them are- appropriateness, technological suitability, competitiveness, performance and functionality. Among these some specific actions such as antagonism towards pathogenic bacteria, production of antimicrobial substances, safety status recognition (nontoxic), evaluation of adherence and colonization can influence their selection ${ }^{2}$.

Antibiotic resistance has revived interest in probiotic cultures for treatment of microbial infections. The concept of competitive exclusion was used to treat salmonella infection in chicken ${ }^{3}$ or preparing probiotic mixture to reduce pathogen carriage in treated animals. Research on controlling enteric pathogens in food to alter risk of food borne infections has been done in animals, but probiotics use targeting specific treatment for human disease has seldomly been done. Isolating pathogens from natural sources offers scope to study pathogen probiotic interaction as they are part of food chain.

Probiotics as a substitute to antibiotics have been successfully used in promoting aquaculture by improving water quality and increasing tolerance to stress ${ }^{4}$. Aquaculture being part of our food chain may be contaminated with water borne infections of bacterial and viral nature. By using commercial probiotics, we can study their specific treatment by targeting these food or water borne infections.
Hence the current study was designed to evaluate commercial probiotics for their properties like invitro cytotoxicity, adherence study as well as their antimicrobial properties against isolated prawn pathogens Vibrio parahaemolyticus.

\section{MATERIALS AND METHODS \\ Collection of probiotic samples}

Commercial probiotics Enteroplus and Avant Bact were collected from a pharmacy store in Visakhapatnam, Andhra Pradesh, India and Lactobacillus sp. strain (NCIM2056) was obtained from National Centre for Industrial Microbiology, Pune, India.

\section{Collection of Vibrio parahaemolyticus samples}

The bacterial samples were obtained from hepatopancreas of infected shrimp collected from various aquaculture farms in Godavari dist. of Andhra Pradesh, India.

Isolation and Identification of Probiotic Bacteria

$1 \mathrm{gm}$ of probiotic sample was suspended in saline, vortexed and $1 \mathrm{ml}$ of this sample was enriched with De Man, Rogosa and Sharpe (MRS) broth. Incubation was done for $24 \mathrm{~h}$ at $37^{\circ} \mathrm{C}$. This enriched sample was used to inoculate MRS agar, observe colonies after incubation. Identification of probiotic samples was done as outlined in Bergey's manual of systemic bacteriology 5 .

Isolation and Identification of Vibrio parahaemolyticus

Bacteria obtained from hepatopancreas of shrimp were plated on Thiosulphate Citrate Bile salt Sucrose (TCBS) agar and incubated at $37^{\circ} \mathrm{C}$ for 24-48h. Identification and further characterization of Vibrio samples (V44,V45,V46) was done as described in Bergey's manual of systemic bacteriology 6 .

Invitro evaluation of efficacy of probiotics against Vibrio parahaemolyticus by agar diffusion method

Vibrio parahaemolyticus isolated from shrimp were used to study antibacterial ability of probiotic samples Enteroplus, Avant Bact and Lactobaciilu sp. (NCIM2056) using well diffusion technique ${ }^{7}$. Vibrio samples isolated from plates were suspended in $2 \mathrm{ml}$ sterile saline, vortexed to create uniform suspension. Turbidity was adjusted within $15 \mathrm{~min}$ of preparation. Probiotics overnight cultures were prepared, centrifuged at 
3000 rpm for $5 \mathrm{~min}$, supernatant mixed with saline solution and used for assay. Cipro stock solution was prepared suitable dilutions made and used as standard for assay.

Invitro Cytotoxicity of commercial probiotic samples by MTT Assay

Cytotoxic screening of probiotic samples was done using MTT assay ${ }^{8}$. $100 \mu$ l of different probiotic samples were prepared. Cell count of

Table 1. Zone of inhibition ( $\mathrm{mm}$ )

\begin{tabular}{lcccc}
\hline Samples & V44 & V45 & V46 & $\begin{array}{c}\text { Mean and } \\
\text { standard } \\
\text { deviation }\end{array}$ \\
\hline Cipro & 25 & 25 & 25 & 25 \\
Enteroplus & 13 & 14 & 14 & $13.66 \pm 0.46$ \\
Avantbact & 10 & 12 & 10 & $10.66 \pm 0.93$ \\
Lactobacillus & 13 & 13 & 11 & $12.33 \pm 0.93$ \\
(NCIM2056) & & & & \\
Water & 0 & 0 & 0 & 0 \\
\hline
\end{tabular}

Cipro-Ciprofloxacin, V44,V45,V46-Vibrio parahaemolyticus samples

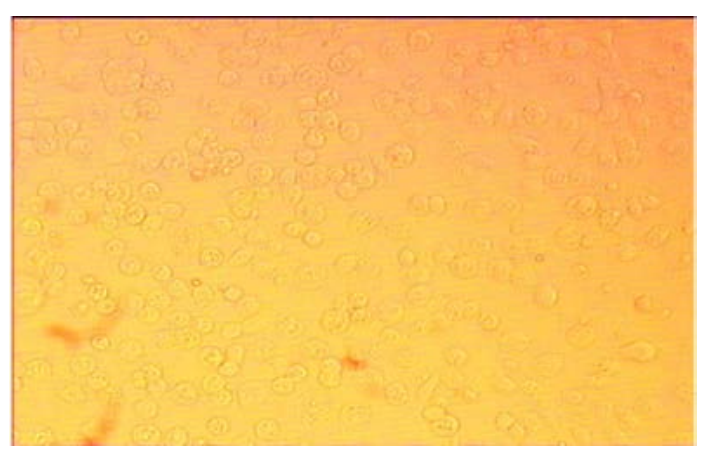

Fig. 1. Avant Bact. Caco cell line

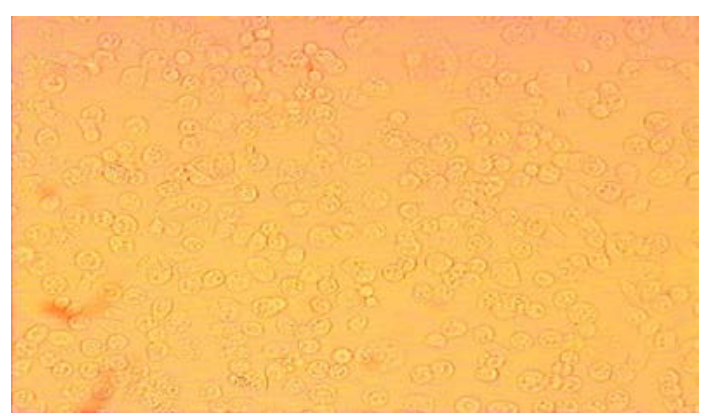

Fig. 3. Lactobaciilu sp(NCIM2056) Caco cell line cell culture was adjusted. Probiotic samples were added to cell culture. Microscopic observations were carried out. The absorbance was measured and $\%$ cell viability calculated for different concentration of probiotic. From dose response curve the concentration of probiotic needing to inhibit cell growth by $50 \%$ was generated

Table 2. Cytotoxicity studies

\begin{tabular}{lcc}
\hline S. No. & $\begin{array}{c}\text { Sample } \\
\text { Description }\end{array}$ & $\begin{array}{c}\text { CaCO-2 } \\
\text { IC50 } \mu \mathrm{g} / \mathrm{ml}\end{array}$ \\
\hline 1 & EP & 50.60501 \\
2 & AB & 104.7745 \\
3 & LB & 58.13223 \\
\hline
\end{tabular}

Table 3. Percentage adhesion of different probiotic isolates

\begin{tabular}{lcc}
\hline S.No & Probiotic isolate & \% adhesion \\
\hline 1 & EnteroPlus & $10.25 \pm 0.74$ \\
2 & AvantBact & $7.25 \pm 0.82$ \\
3 & Lactobacillus sp. & $7.5 \pm 1.12$ \\
& (NCIM2056) &
\end{tabular}

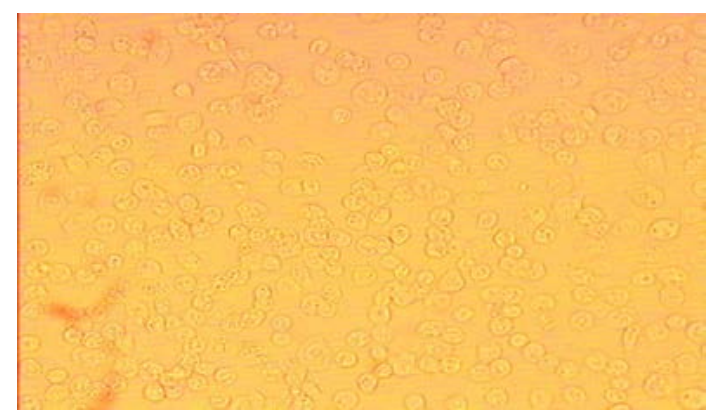

Fig. 2. Enteroplus Caco cell line

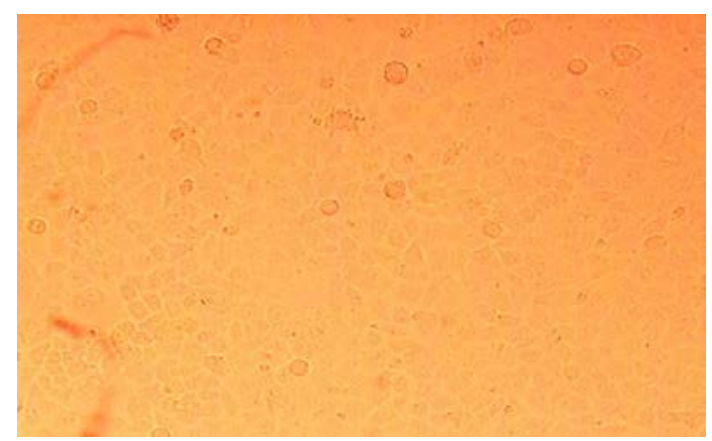

Fig. 4. Caco cell line-normal

Cytotoxixity studies of probiotic sample isolates on Caco cell line observed under inverted microscope 


\section{Invitro Adhesion studies of commercial probiotic samples}

Adhesion studies for probiotic samples were carried out ${ }^{9}$. Probiotic samples were prepared on MRS agar and viability assessed. Cell lines were prepared and monolayer was developed. Adhesion studies of probiotics were carried out on monolayer. Viable adherent bacteria were trypsinized and detached bacteria were plated on MRS agar. \%Adhesion was expressed as number of adhered bacteria to total bacteria used for study.

\section{RESULTS AND DISCUSSION}

In vitro evaluation of efficacy of probiotics against Vibrio parahaemolyticus by agar diffusion method

In well diffusion assay, probiotics showed varying zone of inhibitions against Vibrio parahaemolyticus samples (Table-1) When

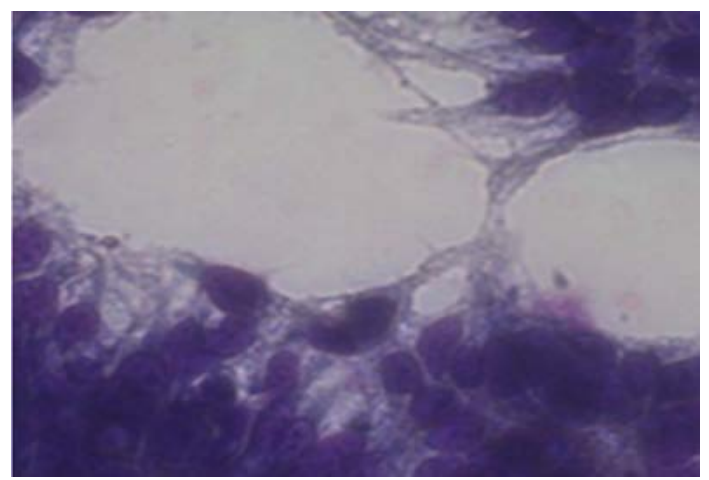

Fig. 5. Blank Caco-2 cell line

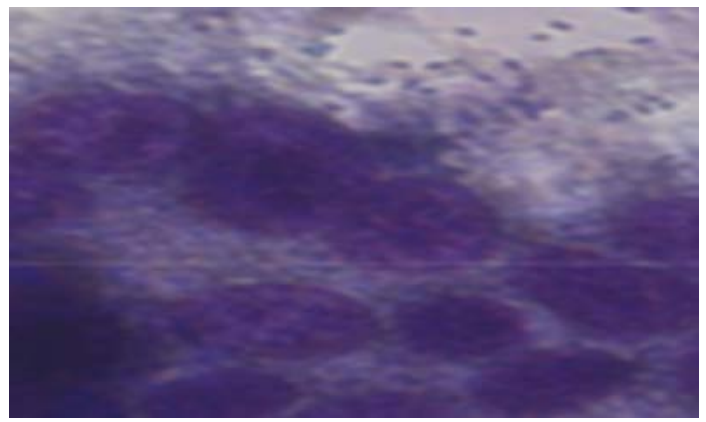

Fig. 7. (AvantBact) Pediococcus acidilactici adhesion study compared with standard ciprofloxacin used for study the zone of inhibition of probiotic samples indicated good inhibitory action against vibrio samples. Ciprofloxacin standard had a zone value of $25 \mathrm{~mm}$. Enteroplus showed an average zone of $13.66 \pm 0.46 \mathrm{~mm}$ followed by Lactobacillus sp. (NCIM2056) a value of $12.33 \pm 0.93 \mathrm{~mm}$ and AvantBact a zone of $10.66 \pm 0.93 \mathrm{~mm}$.

Zone of inhibition can be attributed to production of inhibitory substance by probiotic bacteria. For example, lactic acid bacteria have ability to produce antibacterial peptides which interferes with essential bacterial enzymes or disrupts bacterial membrane permeability ${ }^{10}$. Another mechanism involves probiotic ability to produce enzymes or bacteriocins which inactivates the pathogens ${ }^{11}$. The study suggests certain probiotic effectiveness in minimising vibrio parahaemolyticus, which causes hepatopancreatic necrosis disease in shrimp, a water borne infection.

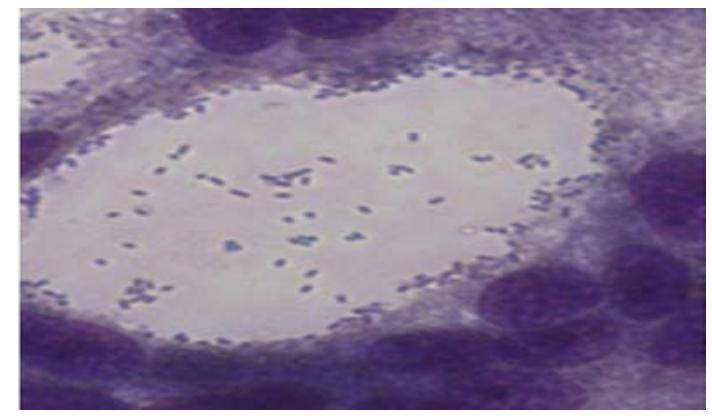

Fig. 6. (EnteroPLus) Lactobacillus rhamnosus GG adhesion study

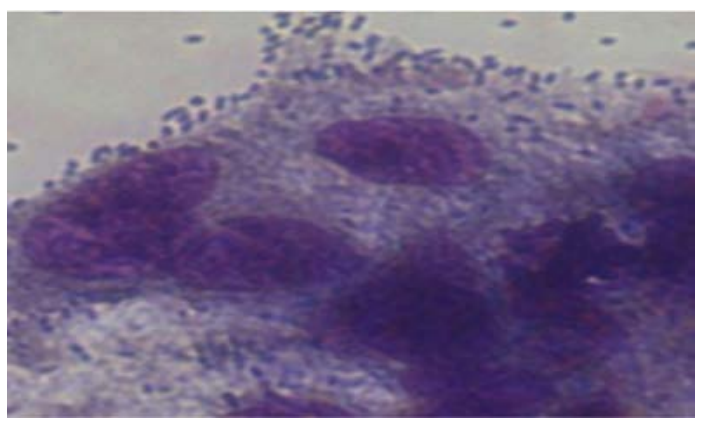

Fig. 8. Lactobacillus sp. (NCIM2056) adhesion study

Adhesion of probiotic sample isolates to Caco-2 cell line observed under inverted microscope (40x) after staining with giemsa stain 


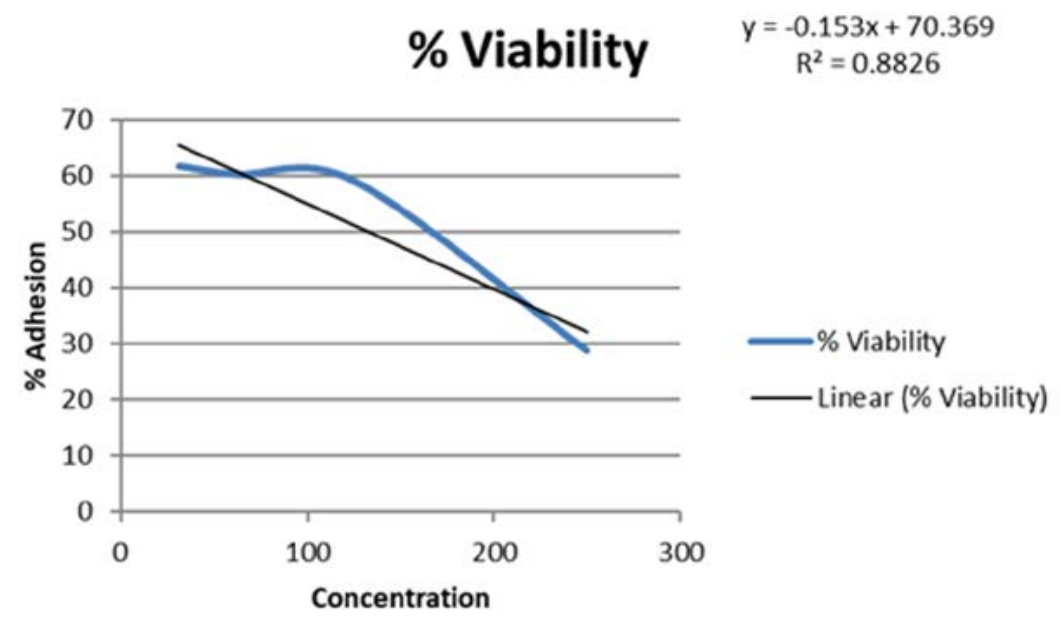

Fig. 9. Enteroplus (\%viability)

$$
\text { \% Viability } \quad \begin{gathered}
\mathrm{y}=-0.153 \mathrm{x}+70.369 \\
\mathrm{R}^{2}=0.8826
\end{gathered}
$$

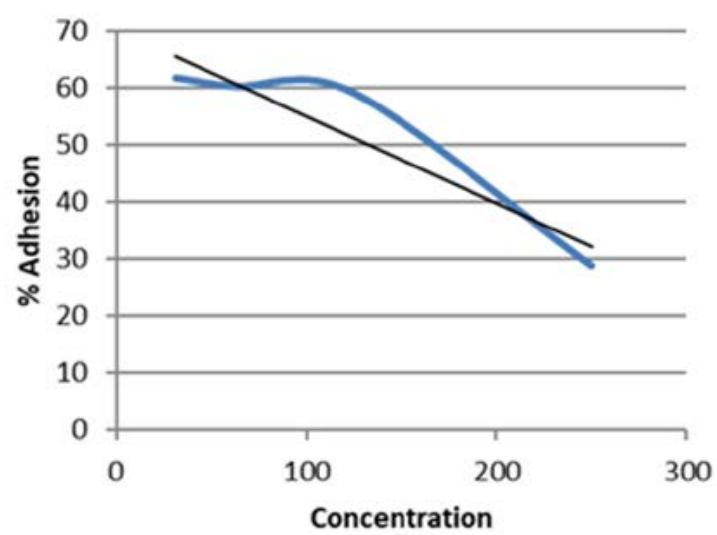

$\%$ Viability

Linear (\% Viability)

Fig. 10. Avant Bact (\%viability)

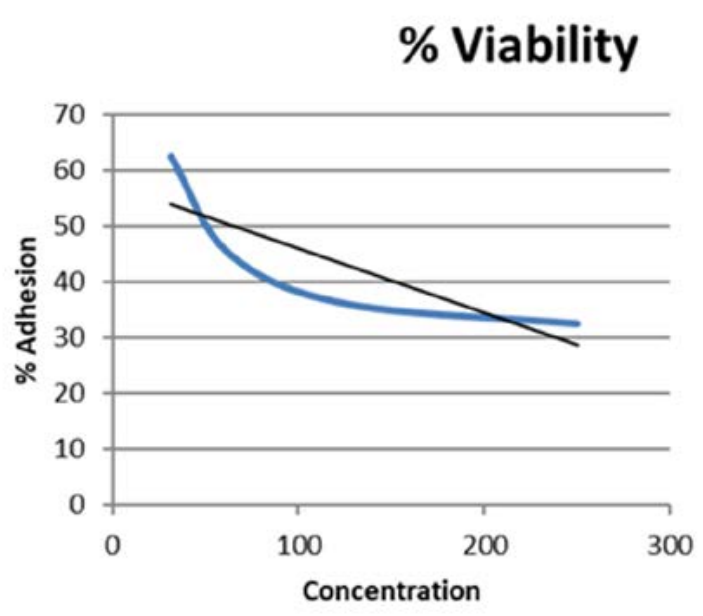

$y=-0.1146 x+57.49$

$R^{2}=0.6937$

$\%$ Viability

— Linear (\% Viability)

Fig. 11. Lactobacillus sp. (NCIM2056) (\%viability) 
In vitro Cytotoxicity of commercial probiotic samples by MTT Assay

Cytotoxic screening of three potential probiotics were carried out using MTT assay. The results showed (Table-2) (Fig.-1-3)(Fig.9-11) probiotic Enteroplus and Lactobacillus sp. (NCIM2056) had a similar IC50 $(\mu \mathrm{g} / \mathrm{ml})$ concentration range of 50.605 and 58.132 . Whereas AvantBact had an $\mathrm{IC} 50(\mu \mathrm{g} / \mathrm{ml})$ concentration of 104.774. Lower IC50 values suggest safety of probiotics used for treatment. Therefore, in invitro cytotoxicity assay done for all probiotics Enteroplus and Avant Bact were found to be safer probiotics in the study.

Both enteroplus and Lactobacillus sp. showed good immune reactive effects when treated against vibrio owing to good IC50 values in MTT assay ${ }^{12}$. Avant Bact having higher IC50 value has been suggested as a probiotic for shrimp in feed optimization, helping to prevent against vibrio infection $^{13}$. Cytotoxicity studies showed ability of cells to survive toxic insults of probiotic samples.

In vitro Adhesion studies of commercial probiotic samples

In present study the level of adherence to Caco cell lines for probiotic samples varied from $7.25 \pm 0.82$ to $10.25 \pm 0.74$ which were in adherence range reported in previous studies ${ }^{14}$. Probiotic isolates had a \%level of adherence of $10.25 \pm 0.74$ for Enteroplus,7.25 \pm 0.82 for Avant Bact and 7.5 \pm 1.12 for Lactobacillus sp. (NCIM2056)(Fig.-6$8)$. Isolates with good adherence capacity serve as promising probiotic candidate and are targeted for in vivo studies in the future.

Adhesion is an ideal parameter to determine colonizing capacity ${ }^{15}$. Probiotics attached to the GIT has an influence on host health by stimulating immune system or by providing conditions for competitive exclusion of pathogenic bacteria ${ }^{16}$. Cell lines are used for adherence study as they possess functional characteristics of mature enterocytes possessing normal epithelial functions ${ }^{17}$. Lactobacillus sp. have good adherence properties to epithelial cell line ${ }^{18}$. Probiotics with good adherence are good candidates for enriching foods to harvest probiotic related benefits.

\section{CONCLUSION}

Given the facts mentioned above, we can suggest that commercial probiotics
Enteroplus, AvantBact and Lactobacillus sp. (NCIM2056) exhibit good antimicrobial properties against pathogen Vibrio parahaemolyticus. The cytotoxicity of probiotics Enteroplus and Lactobacillus sp. assessed revealed good safety levels. The adhesion properties indicated good percentage adhesion for probiotic isolates. Therefore, the results of present study highlight the use of probiotics against pathogens, their safety and adhesion properties. These results indicate the probiotic prospects to investigate their mechanism of action, survival time and host interaction.

\section{ACKNOWLEDGMENTS}

The authors would acknowledge FOR U labs for providing their facility for the study.

\section{CONFLICT OF INTEREST}

The authors declare that there is no conflict of interest.

\section{AUTHORS' CONTRIBUTION}

All authors listed have made a substantial, direct and intellectual contribution to the work, and approved it for publication.

\section{FUNDING}

None.

\section{ETHICS STATEMENT}

This article does not contain any studies with human participants or animals performed by any of the authors.

\section{DATA AVAILABILITY}

All datasets generated or analysed during this study are included in the manuscript.

\section{REFERENCES}

1. Neish AS. Microbes in gastrointestinal health and disease. Gastroenterology. 2009;136(1):65-80. doi: 10.1053/j.gastro.2008.10.080

2. Klaenhammer TR, Kullen MJ. Selection and design of probiotic. Int J Food Microbiol. 1999;50(1-2):45-57. doi: 10.1016/S0168-1605(99)00076-8

3. Nurmi E, Rantala M. New aspects of salmonella infection in broiler production. Nature (London). 1973; 241:210-211. doi: 10.1038/241210a0

4. Ladan J, Isteban MA. Administration of Probiotics in the Water in Finfish Aquaculture Systems: A Review. Fishes. 2018;3(3):33:1-13. doi: 10.3390/fishes3030033 
5. Ranjan KG, Sankar GG, Raju DVVS. Isolation and Characterization of Commercial Probiotics. Int J Pharm Sci Rev Res. 2020;11(1):818-825. doi: 10.26452/ijrps. v11i1.1900

6. Ranjan KG, Sankar GG, Raju DVVS. Isolation and Characterization of Vibrio parahaemolyticus in the hepatopancreas of cultured white pacific shrimp - Litopenaeus vannamei. Int J Pharm Sci Rev Res. 2020;11(1):797-805. doi: 10.26452/ijrps.v11i1.1897

7. Kirby WMM, Yoshihara GM, Sundsted KS, et al. Clinical usefulness of a single disc method for antibiotic sensitivity testing. Antibiotics Annu.1957;19561957:892.

8. Kurokawa $\mathrm{M}$, Wadhwani $\mathrm{A}$, Kai $\mathrm{H}$, et al. Activation of Cellular Immunity in Herpes simplex Virus Type 1Infected Mice by the Oral Administration of Aqueous Extract of Moringa oleifera Lam. Leaves. Phytother Res. 2016;30(5):797-804 doi: 10.1002/ptr.5580

9. Moussavi M, Adams MC. An in vitro study on bacterial growth interactions and intestinal epithelial cell adhesion characteristics of probiotic combinations. Curr Microbiol. 2009;60:327-335. doi: 10.1007/ s00284-009-9545-1

10. Bierbaum G, Sahl HG. Lantibiotics: mode of action, Biosynthesis and bioengineering. Curr Pharm Biotechnol.2009;10(1):2-18. doi: 10.2174/138920109787048616

11. Wohlgemuth S, Loh G, Blaut M. Recent developments and perspectives in the investigation of probiotic effects. Int JMed Microbiol. 2010;300(1);3-10. doi: 10.1016/j.ijmm.2009.08.003
12. Vieira FN, Buglione CC, Mourino JPL, et al. Effect of probiotic supplemented diet on marine shrimp survival after challenge with Vibrio harveyi . Arquivo Brasileiro de Medicina Veterinaria e Zootecnia. 2010;62(3):631638. doi: 10.1590/S0102-09352010000300019

13. Castex $\mathrm{M}$, Lemaire $\mathrm{P}, \mathrm{Wabete} \mathrm{N}$, et al. Effect of probiotic Pediococcus acidilactici on antioxidant defences and oxidative stress of Litopenaeus stylirostris under Vibrio nigripulchritudo challenge. Fish and Shellfish Immunol.2010;28(4):622-631. doi: 10.1016/j. fsi.2009.12.024

14. Duary RK, Rajput YS, Batish VK, Grover S. Assessing the adhesion of putative indigenous probiotic Lactobacilli to human colonic epithelial cells. Indian J Med Res. 2011;134(5):664-671. doi: 10.4103/0971-5916.90992

15. Servin AL, Coconnier MH. Adhesion of probiotic strains to the intestinal mucosa and interaction with pathogens. Best Pract Res Clin Gastroenterol. 2003;17(5):741-754 PMID:14507585. doi: 10.1016/ S1521-6918(03)00052-0

16. Tallon R, Arias $S$, Bressollier $P$, Urdaci, MC. Strainand matrix dependent adhesion of Lactobacillus plantarum is mediated by proteinaceous bacterial compounds. J Appl Microbiol. 2007;102(2):442-451. doi: $10.1111 / \mathrm{j} .1365-2672.2006 .03086 . x$

17. Lea T. Caco-2 cell line. In: Verhoeckx K et al (eds) The impact of food bio-actives on gut health. Springer International Publishing AG, Cham. 2015:103-111. doi: 10.1007/978-3-319-16104-4_10

18. Segers ME, Lebeer S. Towards a better understanding of Lactobacillus rhamnosus GG-host interactions. Microb Cell Fact. 2014;13(Suppl 1):S1-S7. doi: 10.1186/14752859-13-S1-S7 